\title{
The life history of the invasive mullet, Osteomugil engeli (Bleeker, 1858) in Hawaiian estuaries
}

\author{
Eva Schemmel 1 - Keith Kamikawa • Troy Shimoda • \\ Kimberly A. Peyton
}

Received: 24 July 2018 / Accepted: 11 February 2019/Published online: 20 February 2019

(C) The Author(s) 2019

\begin{abstract}
Although mullets (Mugilids) are important estuarine fishes across the world, the biology of many species of mullet have yet to be determined. This is of concern for mullets that are introduced species with unknown impacts on native ecosystems. Here we assess the life history of Osteomugil engeli, an introduced species in Hawai'i. Two populations (Hilo Bay estuary, Hawai'i Island and Maunalua Bay estuary, Oahu) were compared to determine population demographics, spawning season, and size and age at maturity. There were no differences observed between life history metrics between populations sampled. $O$. engeli had year round spawning with recruits and adults co-occurring in similar habitats throughout the year. There was no difference in size $\left(L_{50}\right)$ and age $\left(A_{50}\right)$ at sexual maturity for females and males $\left(\mathrm{L}_{50}: \chi^{2}=0.39, p\right.$ value $=0.53 ; \mathrm{A}_{50}$ : $\chi^{2}=0.29, \mathrm{p}$ value $\left.=0.59\right)$, with $O$. engeli reaching
\end{abstract}

\section{E. Schemmel $(\bowtie)$}

Conservation International, 7192 Kalaniana'ole Hwy, Suite G230, Honolulu, HI 96825, USA

e-mail: eschemmel@conservation.org

K. Kamikawa

Hawaii Institute of Marine Biology, University of Hawaii, 46-007 Lilipuna Road, Kaneohe, HI 96744, USA

T. Shimoda

Department of Land and Natural Resources, Division of Aquatic Resources, 75 Aupuni Street, Hilo, HI 96720-4245, USA

\section{K. A. Peyton}

Department of Land and Natural Resources, Division of Aquatic Resources, Anuenue Fisheries Research Station, 1039 Sand Island Parkway, Honolulu, HI 96819, USA sexual maturity at $140.1 \mathrm{~mm}$ (CI: $139.5-141.6 \mathrm{~mm})$ and 208 days (CI: 204.2-220.9 days). We observed a 4:1 female to male sex ratio and females were found to be on average $23 \mathrm{~mm}$ larger than males $(\mathrm{t}=7.19, p$ value $<0.01)$. O. engeli life history is compared to native species in Hawai'i and among other Mugilids that have been introduced elsewhere. Life history comparisons suggest that introduced mullet populations are better able to respond and adapt to changing habitat and environmental conditions than the native mullet.

Keywords Mullet · Invasive species · Life history · Estuaries

\section{Introduction}

Mugilids are a ubiquitous family found in coastal waters worldwide that can dominate fish fauna in favorable habitats. Dominance of most grey mullet species, especially in estuaries, is directly attributable to their distinct position at the base of coastal food webs as large-bodied detritivores. Estuarine sediments are higher in particulate organic matter and microphytobenthos production compared to marine sediments making estuaries the preferred habitats of sedimentivory mullets, such as Mugil cephalus. Mullets are also economically important fish both commercially and recreationally as well as being vital for subsistence fishing in the Pacific Islands, Asia, Africa, and elsewhere because these fish convert primary productivity directly into fisheries production (Nishimoto et al. 2007; Whitfield et al. 2012; Sakihara et al. 2017). 
The ability to forage primary for microphytobenthos and small filamentous algae may also, in part, contribute to the success of grey mullets as invasive species. As a result of human activities three mullet species are reported to have established populations outside of their native ranges (Randall 1987; Matishov and Luzhnyak 2007; Zenetos et al. 2010; Halim and Rizkalla 2011). A native to the Indian Ocean, the keeled mullet Liza carinata colonized the South-eastern Mediterranean as a Lessepsian immigrant species (Roll et al. 2007). This small-bodied mullet has limited fisheries value in its native range (Torcu and Mater 2000); however, along the Egyptian coast (Suez Bay) where this species is invasive, $18 \%$ of the total catch from 2002 to 2012 was comprised of L. carinata (Hefny et al. 2016). Planiliza haematocheila (also known as Mugil so-iuy or Liza haematocheila), a valuable fisheries and aquaculture species throughout its native range of the western North Pacific and the Sea of Japan, was intentionally introduced to the Azov and Black Seas in the late 1970s and early1980s in efforts to improve aquaculture in the region (Okumuş and Bașçinar 1997). Osteomugil engeli (also known as Mugil engeli, Valamugil engeli, Moolgarda engeli, Chelon engeli, Agonostoma birarae, or Mugil kandavensis) has expansive native distribution in Oceania, which includes Indonesia, Melanesia, Micronesia, and Polynesia as well as warm waters of Northwestern Australia. Interestingly, O. engeli did not establish in the geographically isolated Hawaiian archipelago until it was accidentally included in intentional introduction of a baitfish, Marquesan sardine Sardinella marquesensis, during the 1950s (Randall 1987). O. engeli do not substantially contribute to any fisheries in their native range (IndoPacific ranging from East Africa to the Marquesan and Tuamoto islands; Froese and Pauly 2018) or as exotic species in Hawai'i (Sakihara et al. 2017). This is likely as a result of its small size (up to $224 \mathrm{~mm}$ FL; Peyton et al. 2015) and restrictions on the mesh size of cast nets commonly used to harvest mullet in Hawai'i. Additionally, O. engeli can be confused with similar looking stripped mullet, M. cephalus (appearing as juveniles of this species), therefore often released by pole and line fishers as undersized M. cephalus (known locally as ama ama).

The Hawaiian Islands have two native mullet species, Mugil cephalus (Linnaeus, 1758) and
Neomyxus leuciscus (Gunther, 1872). All three species co-occur in estuary habitats in Hawai' $i$ (Nishimoto et al. 2007). Both O. engeli and $N$. leuciscus utilize nearshore marine waters and estuaries during its adult life, whereas M. cephalus is more reliant on estuary and brackish environments (Nishimoto et al. 2007; Ghasemzadeh 2015). Since introduction, $O$. engeli became well established with reports of up to $80 \%$ of all mullet abundance comprised of $O$. engeli in Kaua i estuaries in the 1970s (Eldredge 1994; Nishimoto et al. 2007). They currently remain a dominant species in Hawaiian estuaries and are known to occur across the main Hawaiian Islands (Nishimoto et al. 2007).

Understanding introduced species life history is important for risk assessments (Kolar and Lodge 2002) and management of invasive species (Morris et al. 2009). Life history metrics allow for the assessment of population growth rates and comparisons to native species to better understand potential species competition (Holt 1977). For example, overlap in spawning or recruitment periods could lead to competitive interactions for resources or other potential indirect impacts such as aggregations of spawners or recruits resulting in increased attention of predators.

Additionally, environment has been found to influence reproductive characteristics (Caselle et al. 2011; Taylor and Choat 2014; Schemmel and Friedlander 2017) and growth in fishes (Gust et al. 2002; Caselle et al. 2011; Donovan et al. 2013). Therefore, it is important to conduct life history studies for introduced species in their introduced range. Furthermore, the sample design should also consider small-scale environmental plasticity to capture the variability within the region.

The biology and life history of $O$. engeli has not been studied in its native range or introduced range, impacting our ability to understand their potential impacts on native populations and estuaries as well as to develop management plans for this invasive species in Hawai'i. We examined age, growth, and reproduction of this abundant invasive in Hawai' $i$ from two estuaries where $O$. engeli are known to be abundant: Hilo Bay and Maunalua Bay. Our objectives were to determine the life history of $O$. engeli in its recipient range for both populations including: population size structure, age and growth, female and male size $\left(\mathrm{L}_{50}\right)$ and age $\left(\mathrm{A}_{50}\right)$ at sexual maturity, and spawning season. 


\section{Methods}

Sampling locations and design

Osteomugil engeli population characteristics were compared in two estuaries: Maunalua Bay (Wailupe) on Oahu and Hilo Bay (Reeds Bay) on Hawai'i Island (Fig. 1). Maunalua Bay is located on the southeastern shore of Oahu and is an $8.7 \mathrm{~km}$ long embayment estuary with freshwater inflow from both perennial and intermittent streams (surface water) as well as coastal ground water. One of 10 watersheds that drain into Maunalua Bay, Wailupe watershed is located in the center of the bay and receives intermittent surface water input, although most of its freshwater is from coastal ground water discharge. At the sampling station substratum is composed of ca. $70 \%$ sediment and ca. $30 \%$ carbonate with a depth range to $0.6 \mathrm{~m}$. Hilo Bay, a crescent shaped $6.5 \mathrm{~km}$ long embayment estuary, is located on Hawai'i Island's eastern shoreline. It is protected by a $4.82 \mathrm{~km}$ long manmade break-wall with freshwater influxes derived from two perennial rivers (Wailuku and Wailoa), smaller perennial streams, and numerous subterranean springs. The sampling station at Reeds Bay (although locally known as a bay, it is a cove within Hilo Bay) is located at the eastern shore of Hilo Bay with freshwater inflow primarily coming from coastal ground water discharge and to a lesser extent through intermittent surface water. The substratum at Reeds Bay is composed of ca. $50 \%$ sediment and $50 \%$ basalt with a depth range to $1 \mathrm{~m}$.

Maunalua Bay sampling occurred from September 2015 to August 2017 and Hilo Bay from July 2016 to August 2017. A fixed sampling station $(100 \mathrm{~m})$ at each site was selected based on data from earlier surveys (DLNR-DAR unpublished data) showing that, within each estuary sampled, $O$. engeli utilizes this area as a sub-habitat hotspot. Sub-habitat hotspot is defined as fixed linear distances along a shoreline that encompass areas that have consistently yielded fish captures from random net casts (monofilament cast nets, see below) with $>75 \%$ probability of capture. The linear boundaries for each sampling station (sub-habitat hotspot) were Maunalua Bay N21.27611 and W-157.76176 to N21.27608 and W-157.76180, and Hilo Bay N19.72559 and W-155.06256 to N19.72649 and W-155.06288).

Monofilament cast nets $(2.44 \mathrm{~m}$ diameter with $0.635 \mathrm{~cm}$ mesh size) were used to sample fish for two different sampling methods. Visual (non-random) method was completed first, followed by a 15 -min rest interval that allowed fish to recover from disturbance and

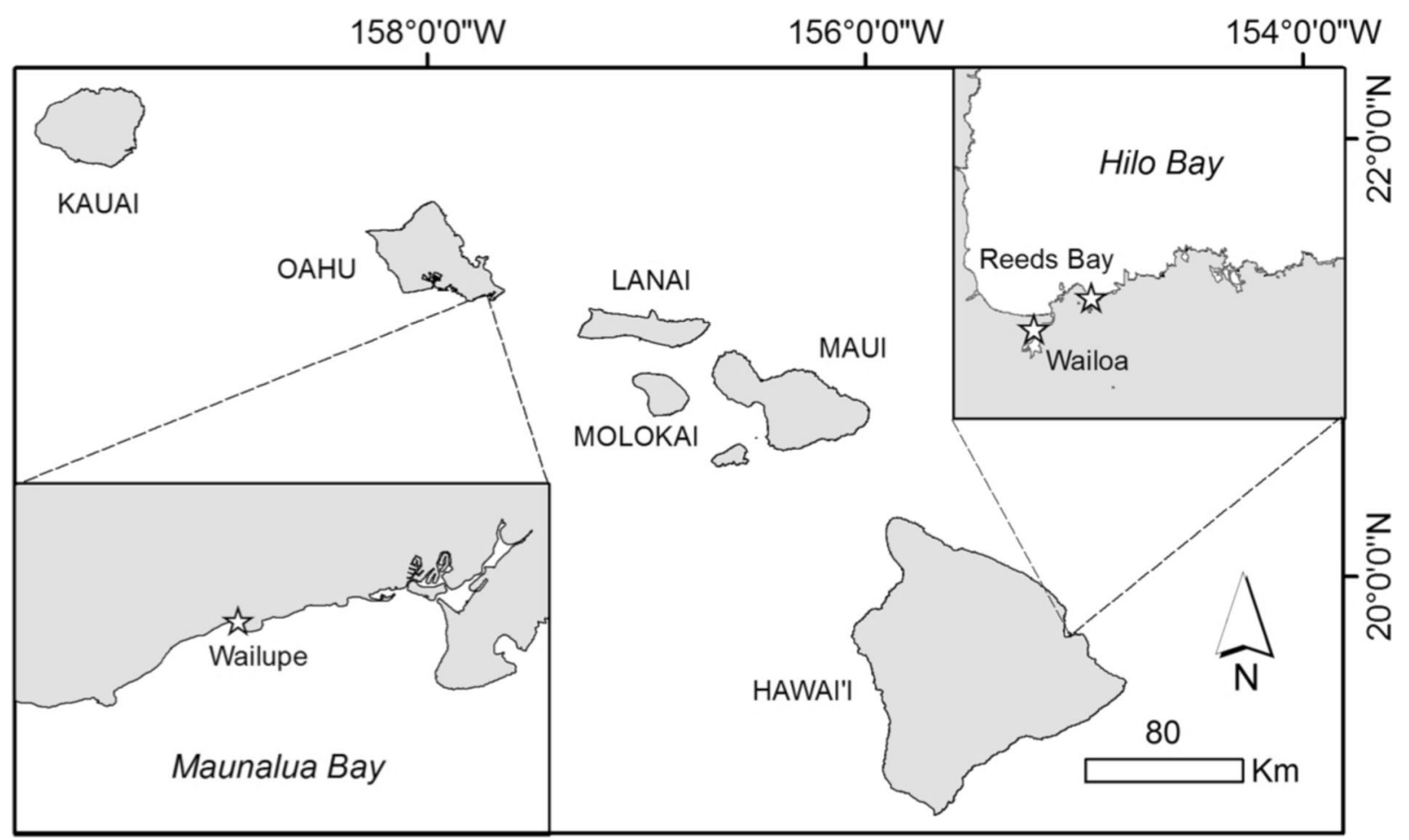

Fig. 1 Sampling locations for Osteomugil engeli in Hilo Bay and Maunalua Bay estuaries 
then, if needed, the area was sampled using Probability of Encounter (POE, systematic) approach. Since Miranda (2007) recommends that length-frequency histograms with $1-\mathrm{cm}$ intervals require $\geq 375$ fish to estimate within $10 \%$ precision with $80 \%$ confidence, whenever possible a minimum of 300 individuals were sampled per month and $O$. engeli population data were pooled into 3-month seasons. When $<300$ individuals were measured per month using visual sampling then POE method was used to supplement the sample effort or, as frequently occurred, to corroborate that $O$. engeli had occurred in low abundance at the time of sampling (Table 1). All sampling took place in the mornings on haphazardly selected dates.

During visual sampling, a fish surveyor actively sampled for $O$. engeli by locating schooling fish within the selected sampling station boundaries and casting on the first school observed. Additionally, a fish surveyor had 32 min of total searching time, which was tracked by an observer on shore using a stopwatch. Transferring fish samples from net to bucket, measurements of specimens, and reloading of a cast net were not counted against searching time. On occasions when no $O$. engeli were visually located or when visibility was limited, haphazard casts were made in microhabitats until all replicates were taken. Some of these microhabitats included coastal ground water plumes, known to attract schools of $O$. engeli (unpublished DLNR-DAR data). Sixteen casts were taken per sampling event.

POE method cast net sampling began at a sampling station boundary with each subsequent cast taken at a distance of 20 paces away from the previous cast (ca. $12 \mathrm{~m}$ ) until the surveyor reached the other boundary. At this boundary, the fish surveyor turned around continued sampling until reaching another boundary or until all samples were taken $(n=16)$. Resampling too close to a position previously sampled along the shoreline was avoided by the fish surveyor offsetting his paces by subtracting five paces on the first cast after the turn was made and then resuming the 20 paces to take each subsequent cast. For both methods, fish are held in aerated buckets, measured to the nearest $\mathrm{mm}$, and immediately returned to the estuary just outside a sampling area boundary.

\section{Biological collections}

To determine female and male size $\left(\mathrm{L}_{50}\right)$ and age $\left(\mathrm{A}_{50}\right)$ at sexual maturity and spawning season, Osteomugil engeli were sampled monthly from both Maunalua
Bay (September 2015 - December 2016) and Hilo Bay (December 2015 - December 2016). Approximately 20 individuals with $\geq 110 \mathrm{~mm}$ fork length (FL) were collected each month at both study sites using monofilament cast nets $(2.44 \mathrm{~m}$ diameter with $0.635 \mathrm{~cm}$ mesh size). A larger area was used to sample fish at both sites for these analyses as compared to sampling populations (see above). This helped to broaden collection of specimens that spanned size ranges of sub-adult to adult and to minimize impacts of extracting fish from the designated sampling areas. Maunalua Bay specimens were collected from the Wailupe watershed N21.27623 and $\mathrm{W}-157.76095$ to $\mathrm{N} 21.27232$ and $\mathrm{W}-157.77069$. Hilo Bay samples were collected from Reeds Bay N19.72559 and W-155.06256 to N19.72649 and $\mathrm{W}-155.06288$. Sampling dates were the same as dates as the population study (see above).

Fish surveyors targeted observed schools of sub-adult to adult sized $O$. engeli for sampling. Fish were held in aerated buckets, measured to the nearest $\mathrm{mm}$, and euthanized by immersion ice bath using a portable cooler in the field with any excess fish returned to the estuary. For each sampling date, the goal was to collect fish from the size range present on that day by sampling the first two fish caught for each $10 \mathrm{~mm}$ FL size bin (110 to $200 \mathrm{~mm} \mathrm{FL).}$ Larger sizes ( $\geq 190 \mathrm{~mm}$ FL) were less commonly sampled throughout the study, therefore, smaller sizes had up to three replicates for each FL size bin to sample approximately 20 individuals per month at each site.

To determine age and growth of $O$. engeli populations, up to five fish per $10 \mathrm{~mm}$ FL size bin ( $\geq 20 \mathrm{~mm}$ FL) were sampled opportunistically at both study sites on haphazardly determined dates from December 2015 - December 2016 using monofilament cast nets ( $2.44 \mathrm{~m}$ diameter with $0.635 \mathrm{~cm}$ mesh size) for individuals $\geq 28 \mathrm{~mm}$ FL and dip nets $(0.15 \mathrm{~cm}$ mesh size) for $\leq 27 \mathrm{~mm}$ FL fish. Dip nets were used for individuals $\leq 27 \mathrm{~mm}$ FL because at this size the fish are too small to be consistently sampled with cast nets used in this study. Fish were euthanized by immersion ice bath using a portable cooler in the field.

Samples were transported to the DLNR-DAR Wailoa Fisheries Research Station (Hawai'i) and DLNR-DAR Ānuenue Fisheries Research Center (Oahu) where metrics were recorded (fork length $(\mathrm{mm})$; total fish weight (MF, $0.00 \mathrm{~g})$ ) and otoliths were extracted. Sagittal otoliths were removed, rinsed in water, and stored until further processing. Fish were dissected to extract gonads, gonad weight (MG, $0.00 \mathrm{~g}$ ), examined for macroscopic gender identification and a midsection of one 
Table 1 Sampling effort ( $\mathrm{n}=$ number of casts) and population $(\mathrm{N})$ sampled using visual method and probability of encounter (POE) for populations of Osteomugil engeli at Wailupe (Maunalua, Oahu) and Reeds Bay (Hilo, Hawai'i) by sampling date each month

\begin{tabular}{|c|c|c|c|c|c|c|}
\hline Site & Date & Visual method $n$ & POE $n$ & Visual method $\mathrm{N}$ & POE N & Total N \\
\hline \multirow[t]{24}{*}{ Wailupe } & 22 Sep 2015 & 16 & 16 & 271 & 0 & 271 \\
\hline & 26 Oct 2015 & 16 & 0 & 376 & - & 376 \\
\hline & 23 Nov 2015 & 16 & 0 & 692 & - & 692 \\
\hline & Dec 2015 & 16 & 16 & 50 & 46 & 96 \\
\hline & Jan 2016 & 16 & 16 & 197 & 27 & 224 \\
\hline & Feb 2016 & 16 & 16 & 58 & 3 & 61 \\
\hline & 17 Mar 2016 & 16 & 16 & 208 & 0 & 208 \\
\hline & 25 Apr 2016 & 16 & 16 & 186 & 28 & 214 \\
\hline & 16 May 2016 & 16 & 16 & 249 & 55 & 304 \\
\hline & 29 Jun 2016 & 16 & 16 & 267 & 1 & 268 \\
\hline & 7 Jul 2016 & 16 & 16 & 249 & 64 & 313 \\
\hline & Aug 2016 & 16 & 0 & 815 & - & 815 \\
\hline & 2 Sep 2016 & 16 & 0 & 539 & - & 539 \\
\hline & 20 Oct 2016 & 16 & 16 & 141 & 2 & 143 \\
\hline & 22 Nov 2016 & 16 & 16 & 75 & 0 & 75 \\
\hline & 13 Dec 2016 & 16 & 16 & 122 & 39 & 161 \\
\hline & 19 Jan 2017 & 16 & 16 & 73 & 89 & 162 \\
\hline & 24 Feb 2017 & 16 & 16 & 246 & 72 & 318 \\
\hline & 30 Mar 2017 & 16 & 16 & 245 & 23 & 268 \\
\hline & 19 Apr 2017 & 16 & 16 & 95 & 24 & 119 \\
\hline & 17 May 2017 & 16 & 16 & 328 & 91 & 419 \\
\hline & 28 Jun 2017 & 16 & 0 & 402 & - & 402 \\
\hline & $28 \mathrm{Jul} 2017$ & 16 & 0 & 615 & - & 615 \\
\hline & 17 Aug 2017 & 16 & 16 & 17 & 8 & 25 \\
\hline \multirow[t]{21}{*}{ Reeds Bay } & 9 Dec 2015 & 16 & 16 & 145 & 0 & 145 \\
\hline & 12 Jan 2016 & 16 & 16 & 227 & 0 & 227 \\
\hline & 11 Feb 2016 & 16 & 16 & 38 & 1 & 39 \\
\hline & 3 Mar 2016 & 16 & 16 & 52 & 58 & 110 \\
\hline & 19 Apr 2016 & 1 & 0 & 0 & - & 1 \\
\hline & 19 May 2016 & 16 & 16 & 301 & 0 & 301 \\
\hline & 2 Jun 2016 & 16 & 16 & 111 & 0 & 111 \\
\hline & 7 July 2016 & 2 & 0 & 319 & - & 319 \\
\hline & 16 Aug 2016 & 5 & 0 & 305 & - & 305 \\
\hline & 15 Sep 2016 & 7 & 0 & 308 & - & 308 \\
\hline & 12 Oct 2016 & 16 & 0 & 418 & - & 418 \\
\hline & 22 Nov 2016 & 16 & 16 & 80 & 1 & 81 \\
\hline & 14 Dec 2016 & 16 & 16 & 1 & 3 & 4 \\
\hline & 4 Jan 2017 & 16 & 0 & 585 & - & 585 \\
\hline & 15 Feb 2017 & 16 & 0 & 637 & - & 637 \\
\hline & 8 Mar 2017 & 16 & 0 & 286 & - & 286 \\
\hline & 12 Apr 2017 & 16 & 0 & 983 & - & 983 \\
\hline & 10 May 2017 & 16 & 0 & 613 & - & 613 \\
\hline & 5 Jun 2017 & 16 & 0 & 1027 & - & 1027 \\
\hline & 6 Jul 2017 & 16 & 0 & 938 & - & 938 \\
\hline & 4 Aug 2017 & 16 & 0 & 1504 & - & 1504 \\
\hline
\end{tabular}


gonad lobe was excised and stored in buffered formalin for a minimum of three days.

Tissue processing and histological assessment

Gonads were rinsed overnight in fresh water and rinsed with a series of alcohol dilutions (30\% and 50\%) for $30 \mathrm{~min}$ and stored in $70 \%$ ETOH until processing. Gonad samples were sent to the University of Hawai' $i$ John A. Burns School of Medicine histopathology lab, embedded in paraffin, sectioned at $5 \mu \mathrm{m}$, and counter stained with Hematoxylin and Eosin.

Female reproductive state was assigned based on a schema modified from Brown (Brown-Peterson et al. 2011) (Table 2; Fig. 2). Resting females were distinguished from immature females by evidence of past spawning events including a thick ovarian wall, postovulatory follicles, and atresia (Fig. 2). Spawning capable females were distinguished from developing females by the presence of late stage vitellogenic oocytes (VTIII) and actively spawning females were identified by the presence of hydrated oocytes (Fig. 2). Males were classified as mature if spermatozoa were present (Fig. 3). Student T-Tests were done to compare male and female fish sizes (FL) at and between locations. Difference in female and male size between locations was assessed with a one-way ANOVA with Tukey Honest Significant Difference Test.

Sexual maturity and spawning seasons

Size at sexual maturity $\left(\mathrm{L}_{50}\right)$ and age $\left(\mathrm{A}_{50}\right)$ at sexual maturity was assessed as the size or age at which $50 \%$ of individuals of a given gender are reproductively mature based on a logistic regression model with binomial family and logit link function (Chen and Paloheimo 1994). Size at maturity was assessed using $5 \mathrm{~mm}$ fork length bins and age at maturity was assessed using 10 day age bins. Likelihood ratio tests were done to assess differences $\mathrm{L}_{50}$ between locations and between genders at each location.

Spawning season was assessed at Hilo Bay and Maunalua Bay by comparing monthly gonadosomatic index (GSI). GSI was assessed as:

$G S I=\frac{G M}{G F M} X 100$

where GM is the gonad mass and GFM is the gonad free fish mass.

Spawning season was also confirmed through analysis of the monthly frequency of reproductive states. Months with females in either spawning capable and actively spawning status were considered within the spawning season.

Age determinations

The right sagittal otolith was analyzed first $(92 \%$ if the time) unless it was missing or broken, in which case the left sagittal otolith was used. Otolith length $(\mathrm{mm})$ was measured from the anterior to posterior end with a caliper and otolith weight $(\mathrm{g})$ was measured using a sensitive scale. Each otolith was mounted on a glass slide using Crystal bond ${ }^{\mathrm{TM}}$ with the anterior end protruding over the slide, such that the visible opaque otolith core was inside of the edge of the slide. The anterior end was then ground against $40 \mu \mathrm{m}$ grit lapping film using a Crystal master ${ }^{\mathrm{TM}}$ until it was flush with the slide. This polished end is then mounted face down on the slide and the posterior end is

Table 2 Reproductive state classification schema for female Osteomugil engeli

\begin{tabular}{|c|c|c|}
\hline Reproductive state & Mature & Diagnostics \\
\hline Undeveloped & No & $\begin{array}{l}\text { Ovaries with oogonia and primary growth (PG) oocytes (chromatin-nucleolus and perinucleolar) present. } \\
\text { Thin ovary wall. }\end{array}$ \\
\hline Developing & Yes & Cortical alveolar oocytes, and/or early vitellogenic oocytes, VTI and/or VTII, present. \\
\hline Spawning Capable & Yes & $\begin{array}{l}\text { Presence of late stage vitellogenic oocytes (VT IIII), identified by dramatic increases } \\
\text { in oocyte size and uniform distribution of yolk. }\end{array}$ \\
\hline Actively Spawning & Yes & $\begin{array}{l}\text { Contains fully hydrated oocytes. May contain postovulatory follicles (POFs) and retained } \\
\text { oocytes post spawning. }\end{array}$ \\
\hline Resting & Yes & $\begin{array}{l}\text { Regressing or regenerating ovary. The ovary wall is thick, does not contain healthy } \\
\text { vitellogenic oocytes, and the ovary may contain unabsorbed material from past spawning events } \\
\text { (atretic oocytes and POFs). }\end{array}$ \\
\hline
\end{tabular}


Fig. 2 Female Osteomugil engeli reproductive stages. a) Immature ovary with thin ovary wall and primary growth oocytes b) developing ovary with primary growth and vitellogenic I oocytes, c) spawning capable ovary with vitellogenic III oocytes, d) actively spawning individual with hydrated oocytes, e) resting individual with evidence of recent spawning including post ovulatory follicles, f) resting ovary with thick ovarian wall, primary growth oocytes, and large melano-macrophage centers. Ovarian wall $(\mathrm{OW})$, primary growth oocytes (PG), vitellogenic I (VTI), vitellogenic III (VTIII), hydrated $(\mathrm{H})$, post ovulatory follicle (POF), melano-macrophage center (MMC). Scale bar is $100 \mu \mathrm{m}$
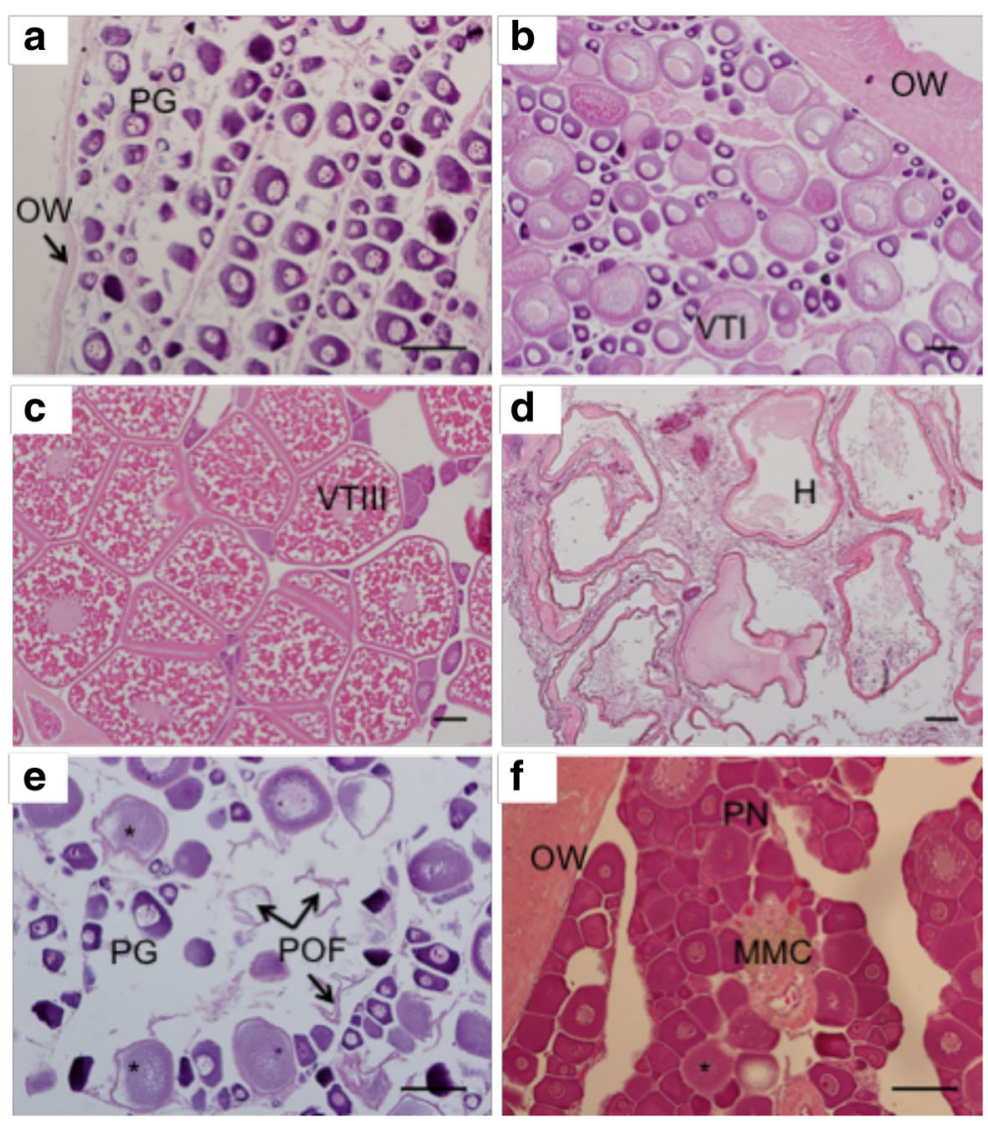

ground down to produce a transverse section. Series of manual polishing with $9 \mu \mathrm{m}$ and $0.3 \mu \mathrm{m}$ lapping films are used until daily growth increments are visible under a compound microscope.

Consecutive images are taken via a camera mounted on the compound microscope at $200 x$ (eye piece at $10 \mathrm{x}$ and objective at 20x) magnification (otolith images) (Fig. 4). Growth increments were counted, and replicate counts were completed for a subset of the otoliths. An otolith was rejected if the counts deviated $>10 \%$, otherwise the mean count was used as the age.
Age and growth

To determine growth rate, three different models were compared: von Bertalanffy, linear, and power. The von Bertalanffy growth (Ricker 1987; Choat and Robertson 2002) was assessed as

$L_{t}=L_{\infty}\left[1-e^{-k\left(t-t_{0}\right)}\right]$

where, $L_{t}$ is length at age $t, L_{\infty}$ is mean maximum asymptotic length, $t$ is age in days, $t_{0}$ is the theoretical age at which length is 0 , and $k$ is the Brody growth
Fig. 3 Male Osteomugil engeli reproductive states a) Immature male with spermatogenic tissue. b) Mature male with spermatozoa. Spermatogenic tissue (ST), spermatozoa (S). Scale bar is $100 \mu \mathrm{m}$
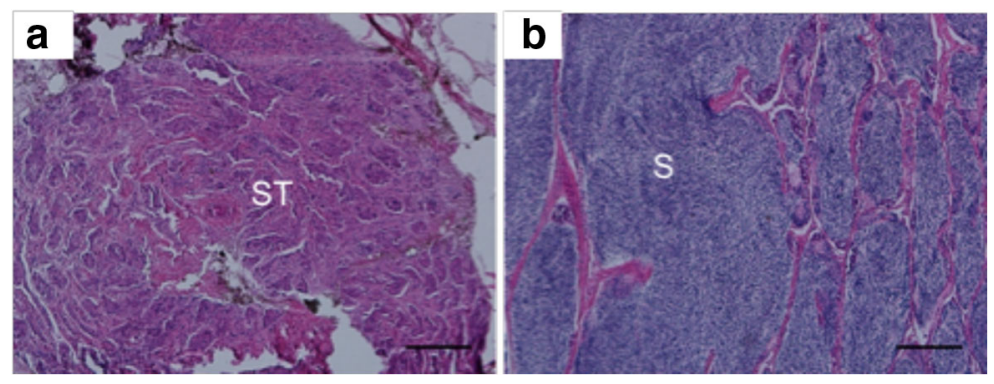


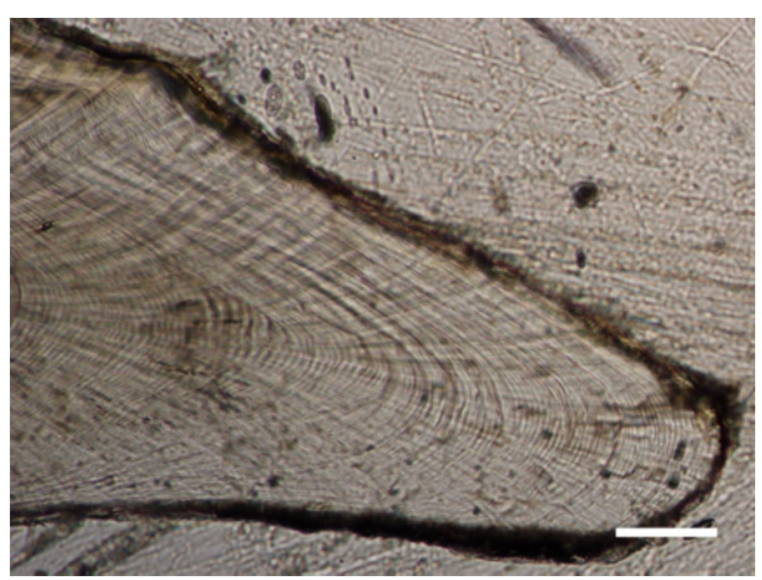

Fig. 4 High resolution image of the anterior end of a sagittal otolith from a $98 \mathrm{~mm}$ Osteomugil engeli collected in Maunalua Bay $($ scale bar $=100 \mu \mathrm{m})$

coefficient. Best model was selected based on coefficient of determination $\left(\mathrm{r}^{2}\right)$ and model differences in Akaike Information Criterion ( $\triangle \mathrm{AIC}$ ) (Akaike 1973).

Mean generational turnover (GT) is an estimate of the average time for a new generation to replace the last generation assuming a stable population (Gaillard et al.
2005). Generational turnover was estimated with the following equation (Gaillard et al. 2005; Depczynski and Bellwood 2006).

$\overline{G T}=A M+\left[\left(T_{\max }-A M\right) / 2\right]$

where AM is the age at first female maturation $\left(\mathrm{L}_{50}\right)$ and $T_{\max }$ is the maximum age. All statistical tests were performed in $\mathrm{R}$ using packages stats, car, and boot ( $\mathrm{R}$ Core Team 2016).

\section{Results}

Population demographics

Over 16,000 Osteomugil engeli individuals were monitored using Probability of Encounter (POE) and visual methods with 7088 individuals from Hilo Bay and 8942 from Maunalua Bay. Catch rates fluctuated greatly with an average monthly catch from Hilo Bay of $425 \pm 401(\mu \pm \mathrm{sd})$ and Maunalua Bay $295 \pm 203$ (Table 1). O. engeli observed ranged
Fig. 5 Length-frequency distribution of Osteomugil engeli sampled from Hilo Bay, Hawai'i Island from fall 2015 through summer 2017. a) Fall, b) winter, c) spring, and d) summer.

Sampling started in winter 2015 in Hilo so no data is available for A $2015-2016$ a

2015-2016
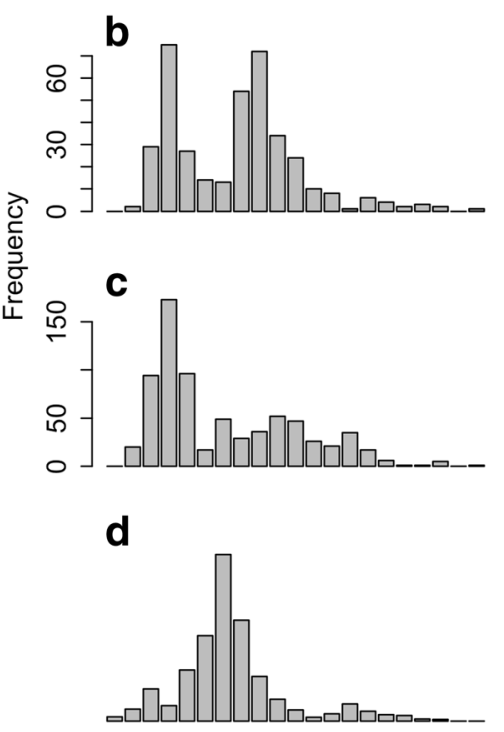
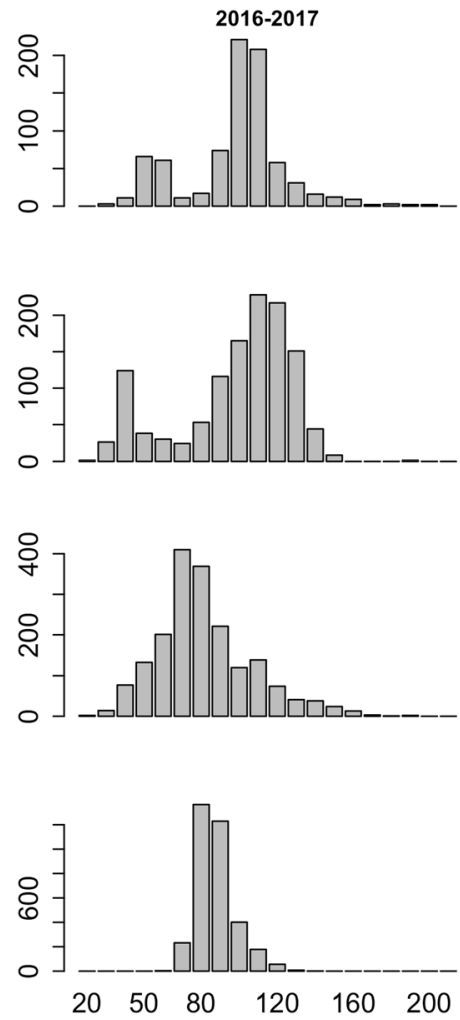

Fork Length (mm) 
Fig. 6 Length-frequency distribution of Osteomugil engeli sampled from Wailupe, Maunalua Bay, Oahu from fall 2015 through summer 2017. a) Fall, b) winter, c) spring, and D) summer
Fig. 7 Length frequency distribution of Osteomugil engeli collected using cast nets and dip nets from a) Hilo Bay (Hawai'i) and b) Maunalua Bay (Oahu)
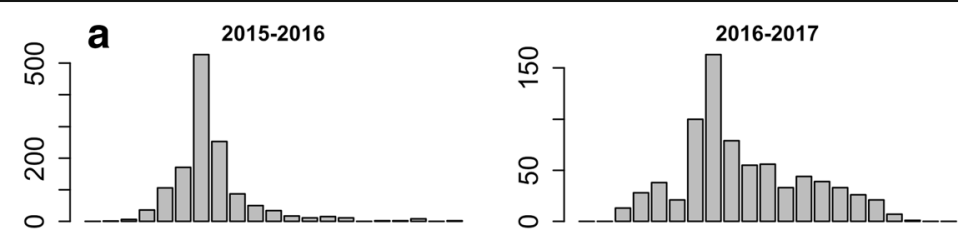

b
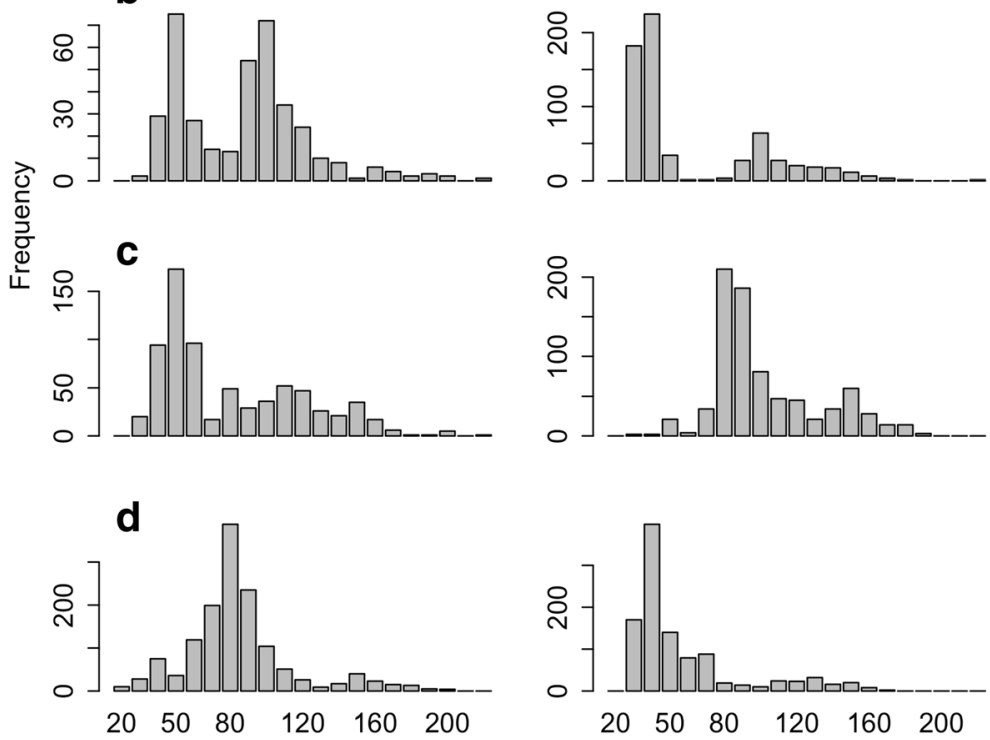

Fork Length (mm)

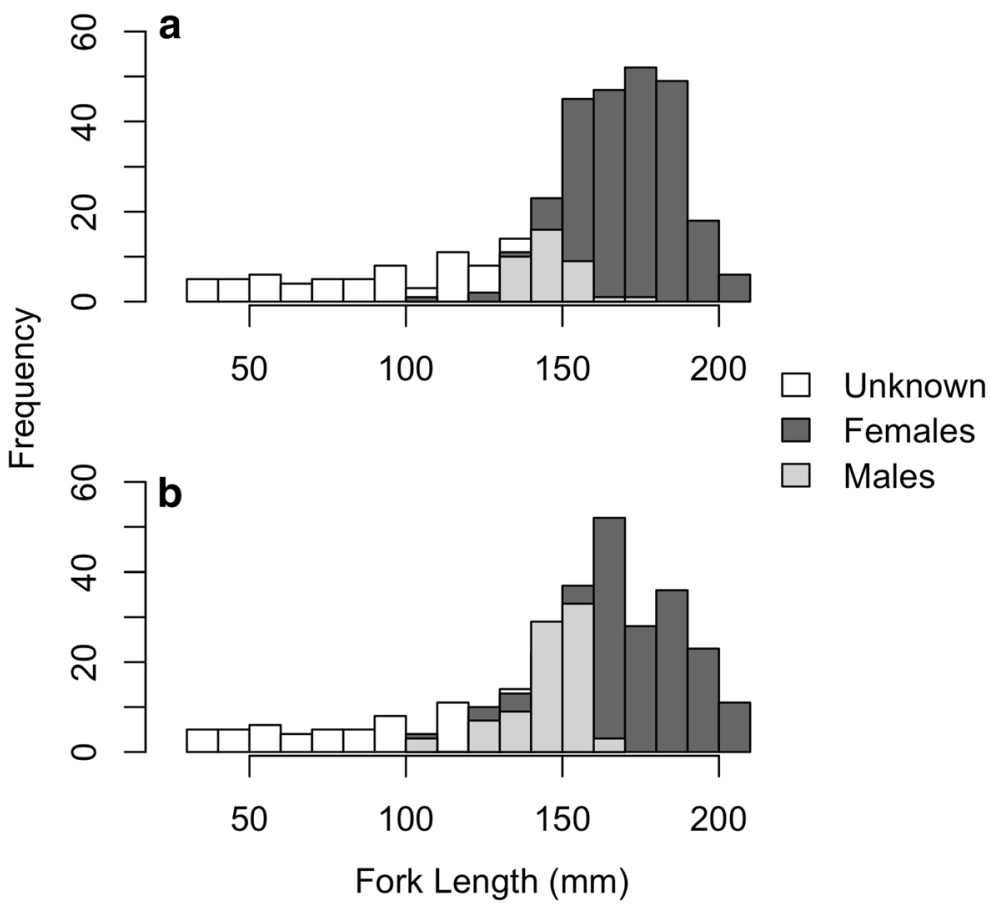


in size from 20 to $229 \mathrm{~mm}$. Recruitment size classes $(<40 \mathrm{~mm})$ through adult size classes $(>140 \mathrm{~mm})$ were encountered each month, co-occurring in the same habitat. Seasonal abundance of each size class was highly variable. Further, while there was no clear temporal pattern in recruitment, recruitment was detected year-round (Figs. 5 and 6).

$O$. engeli biologically sampled ranged from $30 \mathrm{~mm}$ to $209 \mathrm{~mm}$ (FL). Female and male size distributions did not differ between locations $\left(\chi^{2}=\right.$ $0.37, p$ value $=0.54)$. Female $O$. engeli were found to be on average $23 \mathrm{~mm}$ larger than males $(\mathrm{t}=$ 7.19, $p$ value <0.01) (Fig. 7). We found a 4:1 female to male sex ratio from $O$. engeli sampled from a $100 \mathrm{~mm}-209 \mathrm{~mm}$ size distribution. There were 236 females and 84 males sampled from Maunalua Bay and 254 females and 37 males sampled from Hilo Bay.
Sexual maturity and spawning season

A total of 611 sampled Osteomugil engeli were included in the reproductive assessment. Female $O$. engeli size at maturity $\left(\mathrm{L}_{50}\right)$ and age at maturity $\left(\mathrm{A}_{50}\right)$ did not differ between locations $\left(\mathrm{L}_{50}: \chi^{2}=0.42, p\right.$ value $=0.51 ; \mathrm{A}_{50}$ : $\chi^{2}=0.04$, $p$ value $=0.85$ ). There was no difference in size $\left(\mathrm{L}_{50}\right)$ and age $\left(\mathrm{A}_{50}\right)$ at sexual maturity for females and males $\left(\mathrm{L}_{50}: \chi^{2}=0.39, \mathrm{p}\right.$ value $=0.53 ; \mathrm{A}_{50}: \chi^{2}=0.29, \mathrm{p}$ value $=0.59)$. $O$. engeli reach sexual maturity at $140.1 \mathrm{~mm}$ (CI: 139.5-141.6 mm) and 208 days (CI: 204.2220.9 days) (Fig. 8).

$O$. engeli exhibited group synchronous sensu oocyte development, with a synchronous batch of oocytes developing for each spawning event (Wallace and Selman 1981). O. engeli exhibited year-round spawning. High gonadosomatic values and spawning capable females were found throughout the year in both Hilo Bay and
Fig. 8 Osteomugil engeli size and age at maturity using $5 \mathrm{~mm}$ fork length bins and 10 day age bins. a) $\mathrm{L}_{50}=140.1 \mathrm{~mm}(\mathrm{CI}$ : $139.5-141.6 \mathrm{~mm})$ and $\mathbf{b}) \mathrm{A}_{50}=$ 208 days (CI: 204.2-220.9 days). No difference in size or age at maturity was found between females and males
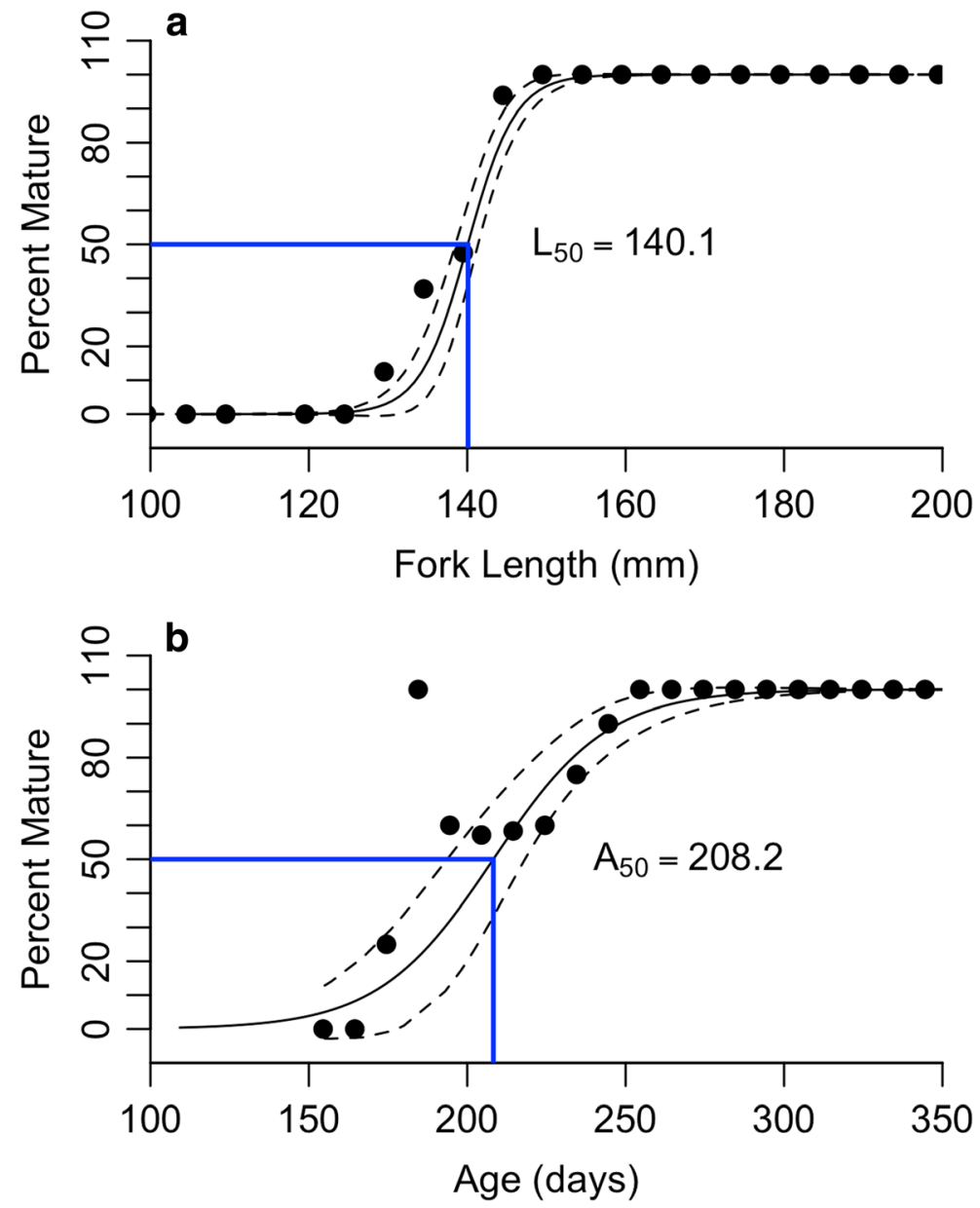


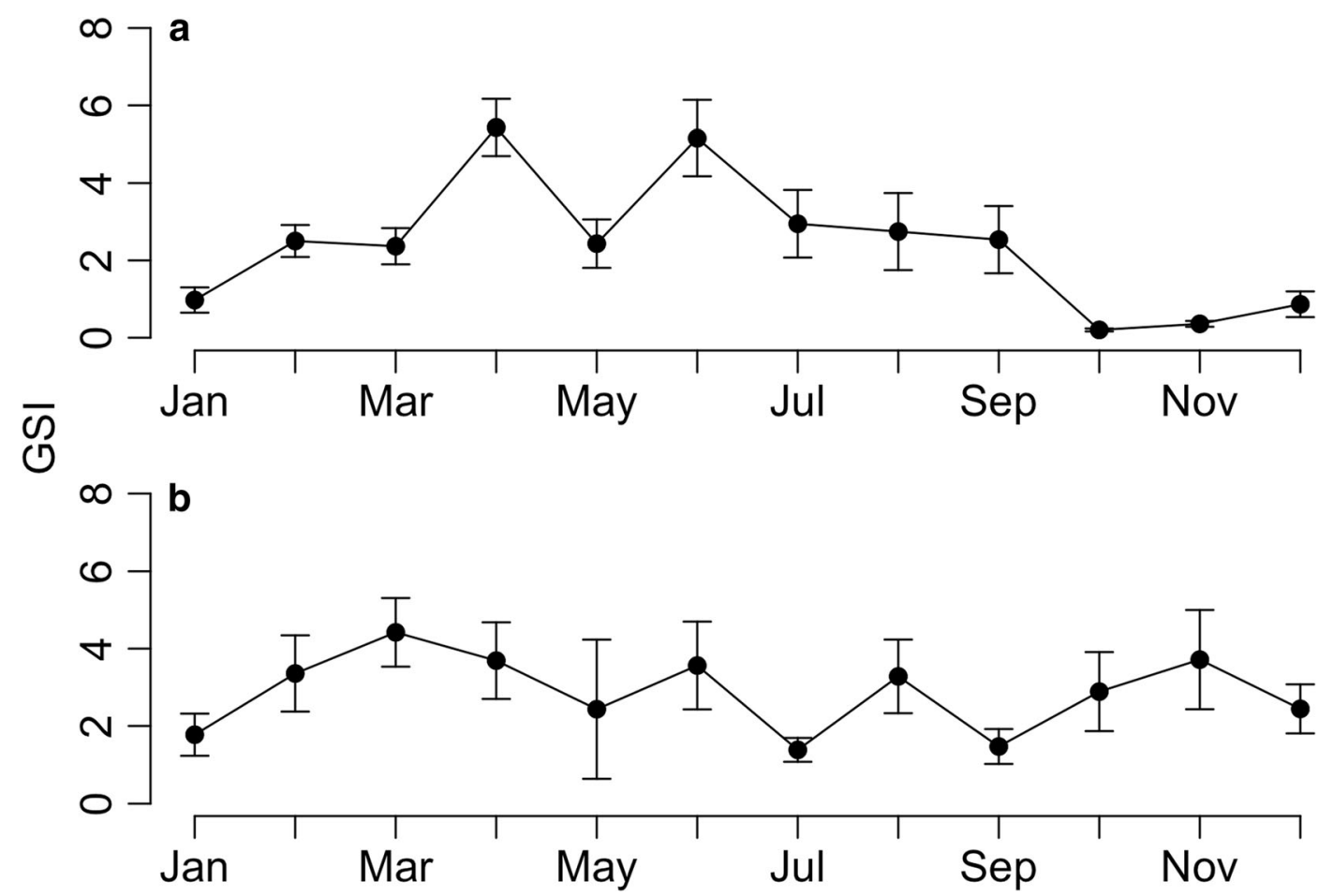

Fig. 9 Mean monthly gonadosomatic index (GSI) for Osteomugil engeli from a) Hilo, Hawai'i, and b) Maunalua, Oahu. Error bars represent standard error

Maunalua Bay (Figs. 9 and 10). Actively spawning females were found from April through December. Year-round spawning activity of this species was also reflected in year-round recruitment to estuaries in Hawai'i (Figs. 5 and 6). There were, however, large fluctuations in young-of-year observed that had no detectable pattern spatially or temporally (Figs. 5 and 6).

Age and growth

A total of 227 Osteomugil engeli were aged (81 from Hilo Bay and 146 from Maunalua Bay) spanning a size range from $30 \mathrm{~mm}$ to $209 \mathrm{~mm}$. Ages ranged from 44 to 349 days $(\mu=249.6$ days $\pm 72.7 \mathrm{sd})$ for Hilo Bay and 36 to 429 days $(\mu=221.7$ days $\pm 81.2 \mathrm{sd})$ for Maunalua Bay. The oldest fish was 429 days old $\left(\mathrm{T}_{\max }\right)$ and $185 \mathrm{~mm}$ FL. Generational turnover was estimated at 215 days or approximately seven months.

$O$. engeli, individuals with unknown gender, males, and females were assessed together. The von Bertalanffy growth model $\left(\mathrm{r}^{2}=0.82\right)$ was the best-fit model followed by power $\left(\triangle \mathrm{AIC}=21.0, \mathrm{r}^{2}=0.81\right)$ and linear $\left(\Delta \mathrm{AIC}=38.8, \mathrm{r}^{2}=0.79\right)$ growth models. O. engeli show asymptotic growth with growth rates slowing as fish reach maximum size $\left(\mathrm{FL}=278.71 *\left(1-\mathrm{e}^{(-0.0036 \text { (Age- }}\right.\right.$ 19.7)), Fig. 11). Females and males exhibited differential growth patterns $(\mathrm{F}=2.69, p$ value $<0.01)$, with males reaching smaller maximum sizes than females of a similar age (Fig. 11).

\section{Discussion}

Like many other smaller bodied mullet species, the life history of Osteomugil engeli was previously unknown. Hawai'i populations of $O$. engeli were found to exhibit year round spawning and young size at maturity; both aspects of this species' life history that likely contribute to this its successful invasion of Hawaiian estuaries after an accidental introduction.

There were no observed differences in population growth rates, size at maturity, or spawning seasons between our two sampling locations. It is likely that different environmental conditions influence growth and reproductive characteristics between these two populations but since there was not a distinct spawning season we did not detect variable in the spawning season between locations. Additionally, due to a young size at 


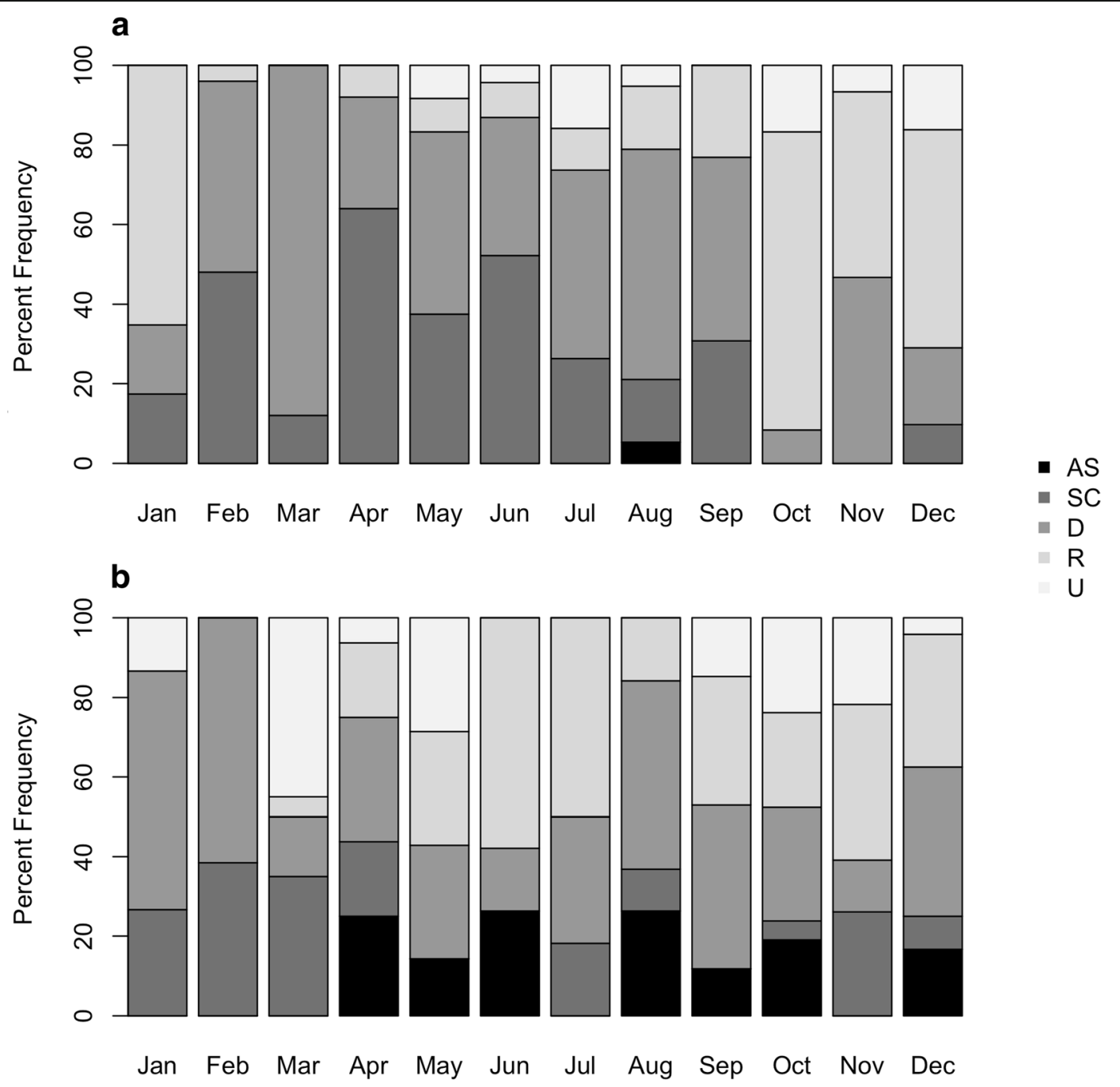

Fig. 10 Reproductive state frequency of Osteomugil engeli in a) Hilo and b) Maunalua Bay. Refer to Table 2 for descriptions of reproductive state. $\mathrm{AS}=$ Actively Spawning, $\mathrm{SC}=$ Spawning Capable, $\mathrm{D}=$ Developing, $\mathrm{R}=$ Resting, U=Undeveloped

maturity, there was not much time for environmental influence on maturation. However, there were variable peaks in recruitment over the two years of monthly sampling, indicating that these recruitment peaks maybe in response to environmental factors yet to be determined.

We saw no size-dependent change in habitat use among juveniles, subadults, and adults because all were co-occurring. O. engeli (adults $>140 \mathrm{~mm}$ ) may be less abundant in our samples for several possible reasons. Adults likely have a larger home range than juveniles and our $100 \mathrm{~m}$ sampling area many have been too small to adequately sample full adult range. Although adults were observed to swim in schools through both sampling sites, compared to juveniles and subadults, adults were better at avoiding net capture by swimming in smaller, looser schools and rapidly moving to outside the sampling area.

Native M. cephalus spawn during the winter and spring in Hawai'i. M. cephalus spawning generally occurs from December - February (Honebrink 1990) but can fluctuate slightly from year to year (Schemmel unpublished research). Annual recruitment of M. cephalus to estuary habitats occurs in spring (Major 1978), whereas we found recruitment of $O$. engeli yearround.

The introduced populations of $O$. engeli in Hawai'i become reproductively mature at a young age (208 days) and small size $(140 \mathrm{~mm}$ ) compared to native mullet. $M$. cephalus size and age at sexual maturity is 


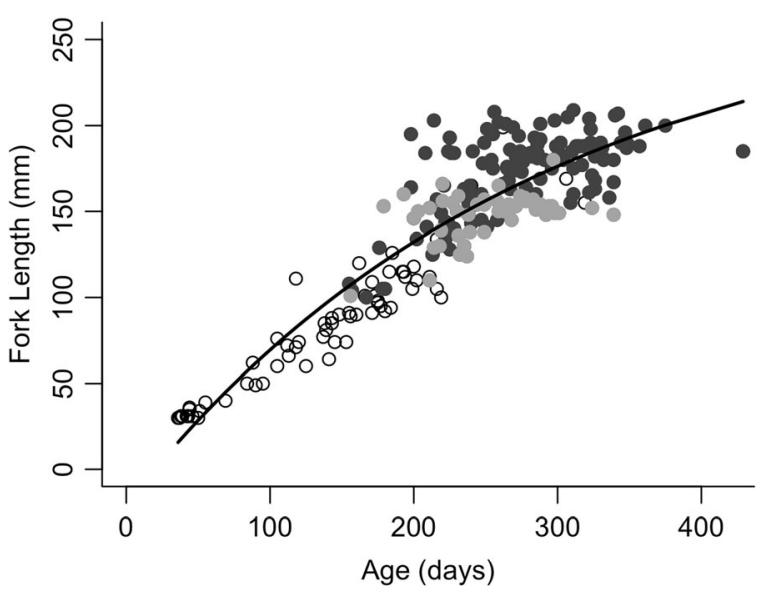

Fig. 11 von Bertalanffy growth curve $(F L=278.71 *(1$ $\mathrm{e}^{(-0.0036(\text { Age-19.7))})}$ for Osteomugil engeli $($ Males = gray circles, Females $=$ dark gray circles, Unknown gender $=$ open circles $)$

unknown for Hawai'i populations however studies from other location suggest that $M$. cephalus reach sexual maturity around 3 to 4 years old (Tung 1981; Smith and Deguara 2002; Whitfield et al. 2012) and at a size around 310-380 mm SL (Apekin and Vilenskaya 1979; Smith and Deguara 2002).

The life history of the other native mullet to Hawai'i, Neomyxus leuciscus (known locally as Uouoa), is not known. However, given the strong correlation between maximum length and size at maturity in tropical fishes (DeMartini and Howard 2016) and similar maximum sizes of $O$. engeli and $N$. leuciscus for Hawaiian populations (O. engeli: $224 \mathrm{~mm}, N$. leuciscus: $229 \mathrm{~mm}$; Peyton et al. 2015), it is likely that $N$. leuciscus reaches maturity at a similar size or age as $O$. engeli for Hawaiian populations. However, growth rate as well as gonadal maturation and spawning periods have not been reported for any Neomyxus species.

Osteomugil engeli life history was compared to other introduced mullet species (Planiliza haematocheila and Liza carinata) (Table 3). All three introduced mullet species spend at least part of their life history in estuaries and are microphagous species. P. haematocheila is an euryhaline mullet species that was purposely introduced to Black and Azov Seas because native mullets were in decline due to changing environmental conditions resulting from decreased freshwater discharges and overfishing (Starushenko and Kazanskiǐ 1996). L. carinata is a small-bodied mullet similar in size to $O$. engeli that was introduced in the South Eastern Mediterranean. P. haematocheila and L. carinata were

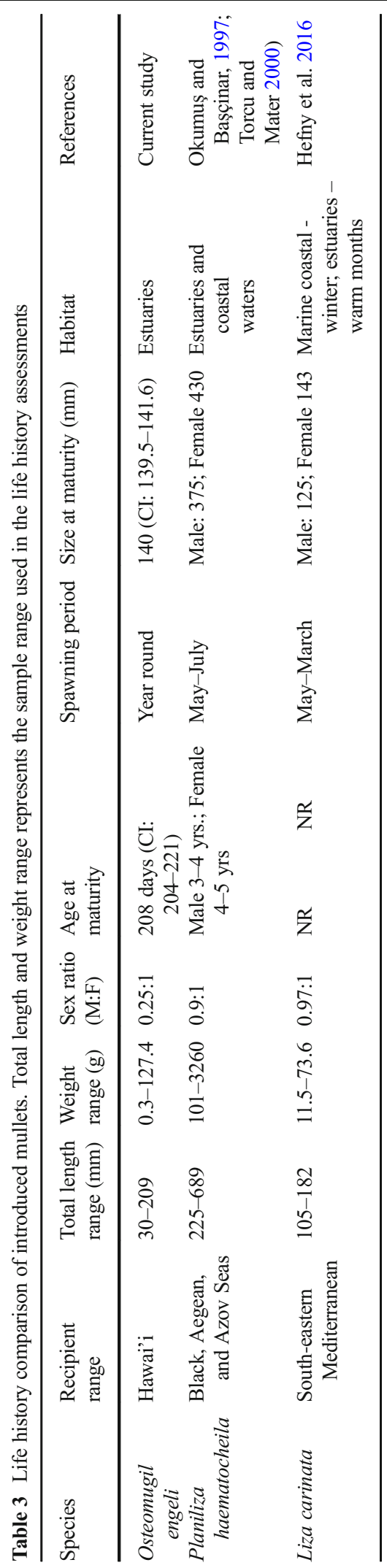


found to be seasonal spawners, May to July, and August to October, respectively (Okumuş and Başçinar 1997; Torcu and Mater 2000). Like M. cephalus, P. haematocheila is a larger bodied mullet (up to $667 \mathrm{~mm} \mathrm{TL}$ ) with an age and size at maturity estimated at $430 \mathrm{~mm}$ and 4-5 years for females and $375 \mathrm{~mm}$ and 2-4 years for males (Okumus and Bascinar 1997; Torcu and Mater 2000). L. carinata has a similar size range as $O$. engeli and similar size at maturity of $125 \mathrm{~mm}$ for male and $143 \mathrm{~mm}$ for females (Hefny et al. 2016).

\section{Management considerations}

It is currently unknown if Osteomugil engeli impacts other estuarine fishes, especially native mullet species. Native and introduced mullet feed mainly on benthic diatoms (microphytobenthos) (Platell et al. 2006; Sakihara et al. 2017). However, native mullet (M. cephalus) have been found to prefer Melosira moniliformis, which is maintained by flood events of freshwater into marine environments (Julius 2007). Fishers even utilize M. moniliformis as bait for native mullet (Julius 2007). Intraspecific competition for microalgae in mullet has been identified for other mullet species (Mullus surmuletus) and found to effect foraging behavior, movements, and energy budget for the species (Levi and Francour 2004; Longepierre et al. 2005). The modification of streams and estuary habitats alters flow regimes and microalgal community structure and thus may give $O$. engeli an advantage over native mullet (Julius 2007). Also, invasive plant canopies that have overgrown many estuaries in Hawai'i can have negative effects on M. cephalus with only limited impacts on the generalist $O$. engeli (Sakihara et al. 2017). Only the other hand, degradation of Hawaiian estuaries and/or overfishing of $M$. cephalus may allow the population of $O$. engeli to increase similar to the scenario for introduced populations of L. haematocheila in Azov and Black Seas (Okumuş and Başçinar 1997).

$M$. engeli may affect other important fishery species that utilize estuaries for part of their life cycle. For example, estuaries are nurseries and important habitats for many of Hawai'i's prized fishery species including jacks (Hawaiian names: ulua, papio, omilu; Caranx ignobilis, Caranx melampygus) (Smith and Parrish 2002). Mullet are an important diet component of juvenile jacks (Smith and Parrish 2002) and likely other piscivores and therefore may have a positive effect on those species.

\section{Conclusions}

The introduced mullet's, Osteomugil engeli, life history shows that they have a population growth rate advantage over native mullet. $O$. engeli reproduce at smaller and younger sizes than either of the native mullet species and spawn year-round. The shorter generational turnover rates for the introduced mullet also allow populations to respond and adapt to changing conditions faster than the native mullet. Growth rates are faster and age at maturity earlier than native populations. Destruction and alteration of stream and estuary ecosystems may exacerbate impacts of $O$. engeli on native systems. Further research is needed to map the distribution of the introduced mullet in Hawai'i and to better understand species and ecosystem impacts of this introduction.

Acknowledgements We thank our field team: N. Hazama, V. Goo, L. Nishiura, T. Shindo, T. Sakihara, R. Young, D. Kaumoo, and A. Brandy; and our administrative support: M. Fujimoto, N. Ahu, B. Anderson, B. Kanenaka, and B. Neilson. A publication of the Hawai'i Office of Planning, Coastal Zone Management Program, pursuant to National Oceanic and Atmospheric Administration Award No NA14NOS4190079, funded in part by the Coastal Zone Management Act of 1972, as amended, administered by the Office for Coastal Management, National Ocean Service, National Oceanic and Atmospheric Administration, United States Department of Commerce; USFWS Federal Aid in Sport Fish Restoration (Grant No. F12A01319); and in part by Conservation International Hawai'i and through a Hawai'i Coral Reef Management Grant through NOAA Coral Reef Conservation Program Award to the State of Hawai'i Department of Land and Natural Resources Division of Aquatic Resources (DAR) (award \#NA13NOS4820014). Histology was done at the University of Hawai'i John A. Burns School of Medicine histopathology lab and was made possible by the through the Ola HAWAII Grant Award U54MD007601. The views expressed herein are those of the author and do not necessarily reflect the views of NOAA or any of its sub-agencies. Fish handling methods were in accordance with principles detailed in Guidelines for the Use of Fishes in Research (American Fisheries Society), and in the U.S. Government Principles for the Utilization and Care of Vertebrate Animals Used in Testing, Research, and administered by the regulating agency (State Department of Land and Natural Resources Division of Aquatic Resources).

Open Access This article is distributed under the terms of the Creative Commons Attribution 4.0 International License (http:// creativecommons.org/licenses/by/4.0/), which permits unrestricted use, distribution, and reproduction in any medium, provided you give appropriate credit to the original author(s) and the source, provide a link to the Creative Commons license, and indicate if changes were made.

Publisher's note Springer Nature remains neutral with regard to jurisdictional claims in published maps and institutional affiliations. 


\section{References}

Akaike H (1973) Information theory as an extension of the maximum likelihood principle. Second International Symposium on Information Theory 1:267

Apekin VS, Vilenskaya NI (1979) A description of the sexual cycle and the state of the gonads during the spawning migration of the striped mullet, Mugil cephalus. J Icthyol 18:446456

Brown-Peterson NJ, Wyanski DM, Saborido-Rey F, Macewicz BJ, Lowerre-Barbieri SK (2011) A standardized terminology for describing reproductive development in fishes. Mar Coast Fish 3:52-70

Caselle JE, Hamilton SL, Schroeder DM, Love MS, Standish JD, Rosales-Casián JA, Sosa-Nishizaki O (2011) Geographic variation in density, demography, and life history traits of a harvested, sex-changing, temperate reef fish. Can J Fish Aquat Sci 68(2):288-303

Chen Y, Paloheimo JE (1994) Estimating fish length and age at $50 \%$ maturity using a logistic type model. Aquat Sci 56:206219

Choat JH, Robertson DR (2002) Age-based studies. In: Coral reef fishes: dynamics and diversity in a complex ecosystem. Academic Press, San Diego, pp 57-80

DeMartini EE, Howard KG (2016) Comparisons of body sizes at sexual maturity and at sex change in the parrotfishes of Hawaii: input needed for management regulations and stock assessments. J Fish Biol 88(2):523-541

Depczynski M, Bellwood DR (2006) Extremes, plasticity, and invariance in vertebrate life history traits: insights from coral reef fishes. Ecology 87(12):3119-3127

Donovan MK, Friedlander AM, DeMartini EE, Donahue MJ, William ID (2013) Demographic patterns in the peacock grouper (Cephalopholis argus), an introduced Hawaiian reef fish. Environ Biol Fish 96:981-994

Eldredge LG (1994) Introductions of commercially significant aqautic organisms to the Pacific Islands in Perspectives in aqautic exotic species management in the Pacific Islands. South Pacific Commission 1:1-129

Froese R and Pauly D (Editors) (2018) FishBase. World Wide Web electronic publication. www.fishbase.org. Accessed April 2018

Gaillard J-M, Yoccoz NG, Lebreton J-D, Bonenfont C, Devillard S, Loison A, Pontier D, Allaine D (2005) Generation time: a reliable metric to measure life-history variation among mammalian populations. Am Nat 166:119-123

Ghasemzadeh J (2015) Biogeography and distribution of Mugilidae in Australia and Oceania. In: Biology, ecology and culture of Grey mullets (Mugilidae), p 85

Gust N, Choat JH, Ackerman JL (2002) Demographic plasticity in tropical reef fishes. Mar Biol 140:1039-1051

Halim Y, Rizkalla S (2011) Aliens in Egyptian Mediterranean waters. A check-list of Erythrean fish with new records. Mediterr Mar Sci 12(2):479-490

Hefny ASED, Abass,OA, El Regal MAA and Ramadan AM (2016) Reproductive biology of keeled fish Liza carinata (Valenciennes, 1836) from Suez Bay, Egypt. Int J Aquac 6(5)

Holt RD (1977) Predation, apparent competition, and the structure of prey communities. Theor Popul Biol 12:197-229
Honebrink R (1990) Fishing in Hawai'i: a student manual. Education Program, Division of Aquatic Resources, Honolulu, Hawai'i. 79 p

Julius ML (2007) Why sweat the small stuff: the importance of microalgae in Hawaiian stream ecosystems. Bishop Mus Bull Cult Environ Stud 3:183-194

Kolar CS, Lodge DM (2002) Ecological predictions and risk assessment for alien fishes in North America. Science (80) 298:1233-1236

Levi F, Francour P (2004) Behavioural response of Mullus surmuletus to habitat modification by the invasive macroalga Caulerpa taxifolia. J Fish Biol 64(1):55-64

Longepierre S, Robert A, Levi F, Francour P (2005) How an invasive alga species (Caulerpa taxifolia) induces changes in foraging strategies of the benthivorous fish Mullus surmuletus in coastal Mediterranean ecosystems. Biodivers Conserv 14(2):365-376

Matishov GG, Luzhnyak VA (2007) Extension of the spawning area of the far eastern mullet Liza haematocheilus (Temminck et Schlegel, 1845) acclimated in the sea of Azov and Black Sea Basin: recent data on reproduction ecology. Doklady biological sciences: proceedings of the Academy of Sciences of the USSR, Biological sciences sections 414:221-222

Miranda LE (2007) Approximate sample sizes required to estimate length distributions. T Am Fish Soc 136(2):409-415

Morris JA, Akins JL, Barse A, Cerino D, Freshwater DW, Green SJ, Munoz RC, Paris C, and Whitfield PE (2009) Biology and ecology of the invasive loinfishes, Pterois miles and Ipterois volitans. Proc Gulf Caribb Fish Inst 61:409:414

Nishimoto RT, Shimoda TE, Nishiura LK (2007) Mugilids in the Muliwai: a tale of two mullets. Biology of Hawaiian Streams and Estuaries. Bishop Mus bull cult. Environ Stud 3:143156

Okumuș İ, Bașçinar N (1997) Population structure, growth and reproduction of introduced Pacific mullet, Mugil so-iuy, in the Black Sea. Fish Res 33(1):131-137

Peyton KA, Sakihara TS, Nishiura LK, Shindo TT, Shimoda TE, Hau S, Akiona A, Lorance K (2015) Length-weight relationships for common juvenile fishes and prey species in Hawaiian estuaries. J Appl Ichthyol 32(3):499-502

Platell ME, Orr PA, Potter IC (2006) Inter- and intraspecific partitioning of food resources by six large and abundant fish species in a seasonally open estuary. J Fish Bio 69:243-262

R Core Team (2016) R: A language and environment for statistical computing. R Foundation for Statistical Computing, Vienna, Austria. URL https://www.R-project.org/

Randall JE (1987) Introductions of marine fishes to the Hawaiian islands. B Mar Sci 41(2):490-502

Ricker WE (1987) Computation and interpretation of biological statistics of fish populations. Dept. of Fisheries and Oceans

Roll U, Dayan T, Simberloff D, Goren M (2007) Characteristics of the introduced fish fauna of Israel. Biol Invasions 9(7):813824

Sakihara TS, Fukunaga A, Peyton KA (2017) Mugilids display distinct trait-mediated patterns with a reinvasion of Para grass Urochloa mutica in a tropical estuary. Fishes 2(2):7

Schemmel EM, Friedlander AM (2017) Participatory fishery monitoring is successful for understanding the reproductive biology needed for local fisheries management. Environ Biol Fish 100:171-185 
Smith GC, Parrish JD (2002) Estuaries as nurseries for the jacks Caranx ignobilis and Caranx melampygus (Carangidae) in Hawai'i. Estuar CoastShelf Sci 55(3):347-359

Smith, K.A. and Deguara, K.L., 2002. Review of biological information and stock assessment for the NSW sea mullet resource. Fishery Resource Assessment Series No. 12. New South Wales Fisheries, Sydney

Starushenko LI and Kazanskii AB (1996) Introduction of mullet haarder (Mugil so-iuy Basilewsky) into the Black Sea and the Sea of Azov (No. 67). FAO 52:197-219

Taylor BM, Choat JH (2014) Comparative demography of commercially important parrotfish species from Micronesia. J Fish Biol 84:383-402

Torcu H, Mater S (2000) Lessepsian fishes spreading along the coasts of the Mediterranean and the southern Aegean Sea of Turkey. Turk J Zool 24(2):139-148
Tung IH (1981) On the fishery biology of the grey mullet, Mugil cephalus Linnaeus, in Taiwan. Rep. Inst. Fish. Biol. Minist. Econ. Aff., Natl. Taiwan Univ 3:38-102

Wallace RA, Selman K (1981) Cellular and dynamic aspects of oocyte growth in teleosts. A Zool 21(2):325-343

Whitfield AK, Panfili J, Durand JD (2012) A global review of the cosmopolitan flathead mullet Mugil cephalus Linnaeus 1758 (Teleostei: Mugilidae), with emphasis on the biology, genetics, ecology and fisheries aspects of this apparent species complex. Rev Fish Biol Fisher 22(3):641-681

Zenetos A, Gofas S, Verlaque M, Çinar ME, Garcia Raso JE, Bianchi CN, Morri C, Azzurro E, Bilecenoglu M, Froglia C, Siokou I (2010) Alien species in the Mediterranean Sea by 2010. A contribution to the application of European Union's marine strategy framework directive (MSFD). Part I. Spatial distribution. Mediterr Mar Sci 11:381-349 